\title{
Variations among animals when estimating the undegradable fraction of fiber in forage samples
}

\section{Variabilidade entre animais na estimação da fração indegradável da fibra em amostras de forragens}

\author{
Cláudia Batista Sampaio"; Daiany Íris Gomes²; \\ José Gilson Louzada Regadas Filho ${ }^{3}$; Edenio Detmann ${ }^{1 *}$; \\ Sebastião de Campos Valadares Filho ${ }^{1}$
}

\begin{abstract}
The objective of this study was to assess the variability among animals regarding the critical time to estimate the undegradable fraction of fiber (ct) using an in situ incubation procedure. Five rumenfistulated Nellore steers were used to estimate the degradation profile of fiber. Animals were fed a standard diet with an 80:20 forage:concentrate ratio. Sugarcane, signal grass hay, corn silage and fresh elephant grass samples were assessed. Samples were put in F57 Ankom ${ }^{\circledR}$ bags and were incubated in the rumens of the animals for $0,6,12,18,24,48,72,96,120,144,168,192,216,240$ and 312 hours. The degradation profiles were interpreted using a mixed non-linear model in which a random effect was associated with the degradation rate. For sugarcane, signal grass hay and corn silage, there were no significant variations among animals regarding the fractional degradation rate of neutral and acid detergent fiber; consequently, the ct required to estimate the undegradable fiber fraction did not vary among animals for those forages. However, a significant variability among animals was found for the fresh elephant grass. The results seem to suggest that the variability among animals regarding the degradation rate of fibrous components can be significant.
\end{abstract}

Key words: Indigestible fiber, internal markers, ruminal degradation

\section{Resumo}

Objetivou-se avaliar a variabilidade entre animais em procedimento in situ em relação ao tempo crítico (tc) necessário para se estimar a fração indegradável da fibra. Foram utilizados cinco novilhos Nelore fistulados no rúmen para se estimar o perfil de degradação da fibra. Os animais foram alimentados com dieta padrão com relação volumoso: concentrado de 80:20. Foram avaliadas amostras de canade-açúcar, feno de capim-braquiária, silagem de milho e capim-elefante in natura. As amostras foram acondicionadas em sacos F57 Ankom ${ }^{\circledR}$ e incubadas no rúmem dos animais por: 0, 6, 12, 18, 24, 48, $72,96,120,144,168,192,216,240$ e 312 horas. Os perfis de degradação foram interpretados usando um modelo misto não linear com um efeito aleatório associado com a taxa fracional de degradação. Para cana, feno de braquiária e silagem de milho não foram verificadas variações significativas entre animais com relação à taxa de degradação da fibra em detergente neutro ou ácido. Isto significa que o tc para se estimar a fração indegradável não variou entre animais para estas forragens. Contudo, variação significativa entre animais foi encontrada para o capim-elefante. Estes resultados parecem sugerir que a

\footnotetext{
${ }^{1}$ Profs., Dept ${ }^{\circ}$ de Zootecnia, Universidade Federal de Viçosa, UFV, Viçosa, MG, Brasil. E-mail: claudiabsampaio@yahoo.com.br; detmann@ufv.br; scvfilho@ufv.br

${ }^{2}$ Prof., Universidade Federal Rural da Amazônia, UFRA, Parauapebas, PA, Brasil. E-mail: daiany.gomes@hotmail.com

${ }^{3}$ Bolsista de Pós-Doutoramento, Dept ${ }^{\circ}$ de Zootecnia, UFV, Viçosa, MG, Brasil. E-mail: gilsonagro@yahoo.com.br

* Author for correspondence
} 
variabilidade entre animais referente à taxa de degradação da fibra pode ser significativa.

Palavras-chave: Degradação ruminal, fibra indigestível, indicadores internos

\section{Introduction}

In nutritional terms, the ruminal degradation of a feed can be assessed based on the concepts of potentiality and effectiveness. Potentiality is an asymptotic characteristic and refers to the limits of ruminal degradation, which are defined by inherent characteristics of the feed. However, feed degradation occurs in a finite time scale and is not only determined by its chemical composition but also depends on the action of enzymatic systems during the time in which the enzyme $\times$ substrate interaction occurs, i.e., the effectiveness of the degradation process (DETMANN; PAULINO; VALADARES FILHO, 2008).

Therefore, the adequacy of the ruminal environment for microbial growth becomes a determining factor for substrate utilization (DETMANN; PAULINO; VALADARES FILHO, 2008; DETMANN et al., 2009). Several characteristics may affect the adequacy of the ruminal system for microbial growth, especially substrate quality, $\mathrm{pH}$, dilution rate and synchrony between the supply of carbohydrates and proteins (BACH; CALSAMIGLIA; STERN, 2005). Nevertheless, certain unique features of the host may be crucial for the efficiency of the degradation process.

Similar performance would be expected when using animals with similar body weights and diets. However, even animals with similar features that are subjected to similar conditions often performed completely different from others in the same group. This result raises the possibility of a significant interference of the animal effect on features of feed use. Host specificity with respect to ruminal bacterial populations has been reported. In these cases, even when the ruminal contents are almost completely changed among animals, the animals' native microbial populations are re-established, confirming the specificity of the host animal regarding the microbial community (WEIMER et al., 2010).

In this context, the influence of an animal's specific microbial species composition on assessments of the ruminal degradation profile would be expected. These influences can be particularly relevant for in situ degradation experiments, which often are not configured using experimental designs that could allow for the control of animal effect on the resulting estimates.

This variability among animals could be more prominent when the undegradable fractions of the neutral detergent insoluble fiber (iNDF) or acid detergent insoluble fiber (iADF) are assessed for use as internal markers. In these procedures, a single incubation time is adopted (CASALI et al., 2008; VALENTE et al., 2011a), and evaluations are often performed in a single animal (TOMICH; SAMPAIO, 2004). Thus, it can be speculated that an animal that is less effective at maintaining its microbial population or has a microbial population that is less efficient with respect to fiber degradation would require a longer incubation period for performing an accurate estimate of the undegradable fraction. If the aforementioned effect is not considered in advance, the concentration of marker could be overestimated, producing biased estimates of fecal excretion, digesta flow or pasture intake.

Therefore, this study aimed to assess the variability among animals with respect to the critical time required for the estimation of the fiber undegradable fraction using an in situ incubation procedure performed with cattle.

\section{Material and Methods}

The experiment was conducted at the Department of Animal Science of the Universidade Federal de 
Viçosa, Viçosa, Minas Gerais state, Brazil.

Five rumen-fistulated Nellore steers with an average body weight of $350 \pm 9 \mathrm{~kg}$ were used to assess the degradation profile of insoluble fiber. All surgical and animal care procedures were conducted according to the regulations of the Brazilian National Council on Control of Animal Experimentation (CONCEA).

Animals were fed a standard diet with an 80:20 forage:concentrate ratio on a dry matter (DM) basis. The diet was composed of fresh elephant grass and concentrate containing $280 \mathrm{~g}$ of crude protein (CP) per kg of DM. The total diet presented approximately $110 \mathrm{~g} \mathrm{CP} / \mathrm{kg}$ DM. The animals were adapted to the diet and the experimental conditions for 12 days prior to incubation. A mineral mixture containing $90 \mathrm{~g} / \mathrm{kg}$ of phosphorus was freely available all time.

Sugarcane (Saccharum sp.), signal grass (Brachiaria decumbens) hay, corn (Zea mays) silage and fresh elephant grass (Pennisetum purpureum cv. Cameroon, 40 days of regrowth) samples were assessed. Wet samples were dried using a forced air oven at $60^{\circ} \mathrm{C}$ and were processed together with hay sample in a knife mill (Thomas Wiley ${ }^{\circledR}$ Model 4, Swedesboro, NJ, USA) to pass through a 2-mm sieve. After that, a part of each sample was processed in the same knife mill to pass through a 1-mm sieve.

Chemical analyses were performed using the samples processed at $1-\mathrm{mm}$ screen sieve. The contents of DM (method INCT-CA no. G-003/1), organic matter (OM; method INCT-CA no. M-001/1), CP (method INCT-CA no. N-001/1), neutral detergent fiber [aNDF; using a heat-stable $\alpha$-amylase (Termamyl 2X, Novozymes) and omitting sodium sulfite; method INCT-CA no. F-002/1] and acid detergent fiber (ADF; obtained sequentially to aNDF; method INCT-CA no. F-004/1) were quantified. All of these analyses were performed according to the standard analytical procedures of the Brazilian National Institute of Science and Technology in Animal Science (INCTCA; DETMANN et al., 2012) (Table 1).

Table 1. Chemical composition of the forages.

\begin{tabular}{lcccccc}
\hline \multirow{2}{*}{ Forage } & \multicolumn{7}{c}{$\mathrm{Item}^{1}$} \\
\cline { 2 - 7 } & $\mathrm{DM}^{2}$ & $\mathrm{OM}^{3}$ & $\mathrm{CP}^{3}$ & $\mathrm{EE}^{3}$ & $\mathrm{aNDF}^{3}$ & $\mathrm{ADF}^{3}$ \\
\hline Sugarcane & 296.0 & 969.5 & 26.5 & 1.50 & 602.9 & 336.0 \\
Signal grass hay & 887.7 & 945.5 & 36.7 & 1.93 & 824.1 & 432.6 \\
Corn silage & 312.6 & 950.2 & 72.7 & 2.75 & 558.0 & 312.2 \\
Elephant grass & 214.1 & 912.1 & 70.2 & 2.13 & 779.1 & 461.9 \\
\hline
\end{tabular}

${ }^{1} \mathrm{DM}$, dry matter; OM, organic matter; CP, crude protein; EE, ether extract; aNDF, neutral detergent fiber assayed with a heat-stable alpha amylase; ADF, sequential acid detergent fiber. ${ }^{2} \mathrm{~g} / \mathrm{kg}$ as-is. ${ }^{3} \mathrm{~g} / \mathrm{kg} \mathrm{DM}$.

Source: Elaboration of the authors.

The incubation procedures were performed using samples processed to pass through a 2-mm sieve. These samples were put in Ankom ${ }^{\circledR}$ F57 bags (Ankom Corp., Macedon, NY, USA) following the ratio of $20 \mathrm{mg}$ of $\mathrm{DM} / \mathrm{cm}^{2}$ of surface area. The bags were then incubated in the rumen of the animals for $0,6,12,18,24,48,72,96,120,144,168,192$, 216, 240 and 312 hours. For each time point, one bag of each sample was incubated in each animal, totalizing 300 bags. The bags were placed in the rumen in a reverse order with respect the incubation time so that the removal occurred at once.

After removal from the rumen, the bags were rinsed in running tap water until the water become clear. During rinsing, the bags were slightly pressed 
by hand to further remove the soluble material.

Bags containing the incubation residues were placed in 120-mL polyethylene pots, and the neutral detergent solution was added (using a heat-stable $\alpha$-amylase and omitting sodium sulfite; $100 \mathrm{~mL} / \mathrm{g}$ of the sample). The pots were sealed and then autoclaved for one hour at $105^{\circ} \mathrm{C}$ (method INCTCA no. F-002/1; DETMANN et al., 2012). After extraction, sequential washes were performed using hot distilled water and acetone. The bags were then sequentially dried at $60^{\circ} \mathrm{C}$ for 48 hours and at $105^{\circ} \mathrm{C}$ for two hours, placed in a dissecator and weighed. Subsequently, a sequential extraction was performed using acid detergent following the same procedures described for neutral detergent extraction (method INCT-CA no. F-004/1; DETMANN et al., 2012).

Prior to incubation, the bags were washed with a boiling neutral detergent solution, hot water and acetone and were then dried and weighed according to previously described procedures for obtaining tares (DETMANN et al., 2012).

The modeling of the NDF and ADF degradation profiles was conducted by assuming that potentially degradable and undegradable fractions constitute intrinsic characteristics of the feed; in addition, the degradation rate is influenced by the characteristics of both the feed and the degradation environment (DETMANN; PAULINO; VALDARES FILHO, 2008). In the latter case, we sought differences between animals (i.e., different environments) maintained under the same feeding conditions.

Under the aforementioned assumptions, the degradation profiles were interpreted using a mixed non-linear model approach based on a first-order exponential model:

$$
Y_{i j}=B \times e^{\left\{-[k d( \pm u)] \times t_{j}\right\}}+U+\varepsilon_{i j}
$$

where $\mathrm{Y}_{\mathrm{ij}}$ is the degradation residue obtained in animal $\mathrm{i}$ at incubation time $\mathrm{j}(\mathrm{g} / 100 \mathrm{~g})$; $\mathrm{B}$ is the potentially degradable fraction $(\mathrm{g} / 100 \mathrm{~g})$; $\mathrm{kd}$ is the fractional degradation rate $\left(\mathrm{h}^{-1}\right)$; $\mathrm{u}$ is a random effect parameter associated with $\mathrm{kd}$, which is assumed to present a normal distribution with a mean of zero and a constant variance; $U$ is the undegradable fraction $(\mathrm{g} / 100 \mathrm{~g})$; and $\varepsilon_{\mathrm{ij}}$ is the random error that is assumed to present a asymptotic normal distribution, with a mean of zero and a variance of $\sigma^{2}$ and to be independent of $\mathrm{u}$.

The model was adjusted to data using the NLMIXED procedure of SAS (Cary, NC, USA, version 9.1). The dual quasi-Newton method was used as an optimization technique and the integration was performed using the adaptive Gaussian quadrature. The estimation of the parameters was performed according to maximum likelihood method. The significance of the variance of $\mathrm{u}$ parameter was evaluated using an asymptotic approach of $t$ distribution (LITTELL et al. 2006). When the null hypothesis $\left(\mathrm{H}_{0}: \sigma_{\mathrm{u}}^{2}=0\right)$ was rejected, it was concluded that there was a variation among animals with regard the degradation rate and, consequently, regarding the minimal or critical time (ct) required to estimate the undegradable fraction.

According to the probabilistic approach suggested by Casali et al. (2008), the ct required to estimate the undegradable fraction (asymptotic value) is defined as the time corresponding to the intersection between the adjusted degradation profile and the upper bound of the asymptotic confidence interval of the undegradable fraction. This critical time could be used as the single incubation time in procedures that attempt to estimate only the fiber undegradable fraction (CASALI et al., 2008; VALENTE et al., 2011b). Thus, the model described in Equation (1) can be rearranged as follows:

$$
c t=\frac{\ln \left(\frac{U B(U)-U}{B}\right)}{-k d}
$$

where ct is the (minimal) critical time required to estimate the asymptote with an asymptotic confidence level of $0.95(1-\alpha=0.95)(h)$, and $\mathrm{UB}(\mathrm{U})$ is the upper bound of the asymptotic confidence interval for the fraction $\mathrm{U}(\mathrm{g} / 100 \mathrm{~g})$. The other terms were previously described. 
Using the probabilistic approach for ct shown in Equation 2 together with the random effect $\mathrm{u}$ associated with $\mathrm{kd}$ (Equation 1), a sensitivity analysis for the influence of the environment on $\mathrm{kd}$, and consequently on ct, was performed using a Monte Carlo simulation method. That sensitivity analysis was performed using the @Risk for Excel 5.5.1 software (Palisade Corporation, Ithaca, NY, USA) with 1000 interactions per feed and fraction (iNDF or $\mathrm{iADF}$ ). In agreement with the assumptions that were presented above, parameters $B$ and $U$ were fixed, and the variability of the kd parameter was simulated based on a probability density function.

To estimate the degradation profiles, we assumed, based on the NLMIXED procedure, that the $\mathrm{u}$ random parameter would exhibit a normal distribution. However, this assumption represents a biological incongruence because it would set lowest and highest limits of $u$ as equal to $\pm \infty$, which could result in negative kd estimates. Therefore, to avoid this incongruence, we assumed that $\mathrm{u}$ would follow a lognormal distribution. As with a normal distribution, the lognormal distribution exhibits two parameters, $\mu$ and $\sigma^{2}$; however, due to logarithmic transformation, the random variable assumes only values greater than zero (TIJMS, 2007).

The simulated values of $\mathrm{kd}$ were inserted in Equation 2, allowing for the formation of a random sample of ct values $(\mathrm{n}=1000)$. Using @Risk software, we performed a fit test of the several probability density functions for the population description of the ct parameter. The discrepancy between the adjusted probability density function and the values of each sample was calculated using the $\chi^{2}$ statistics. It was selected the probability density function that exhibited the lowest $\chi^{2}$ values among all of the assessed distributions.

\section{Results}

No significant variations were observed among the animals $(\mathrm{P}>0.10)$ with respect to the fractional degradation rates of NDF and ADF for corn silage, signal grass hay and sugarcane. In these cases, ct value simulations were not performed due to the non-significance $(\mathrm{P}>0.10)$ of variance of parameter $\mathrm{u}$ (Equation 1). Therefore, assuming that kd did not vary among animals, single average estimates for ct were calculated (Tables 2 and 3). The ct estimates were 165.8, 98.7 and 171.1 hours for iNDF estimation, and 204.1, 100.8 and 180.2 hours for iADF estimation, considering sugarcane, signal grass hay and corn silage samples, respectively.

In contrast to the results for corn silage, signal grass hay and sugarcane, the variance of parameter $\mathrm{u}$ in the fresh elephant grass sample exhibited significance for both NDF $(\mathrm{P}<0.08$; Table 2$)$ and ADF $(\mathrm{P}<0.02$; Table 3$)$ degradation. Samples of $\mathrm{kd}$ for NDF and ADF were produced using a Monte Carlo method, which, in turn, allowed for the construction of ct samples. The lognormal and inverse Gaussian distributions were adjusted to the values for NDF and ADF, respectively (Table 4; Figure 1). 
Table 2. Characterization of degradation profile of neutral detergent fiber of different forages.

\begin{tabular}{lcccc}
\hline \multirow{2}{*}{ Item $^{1}$} & \multicolumn{4}{c}{ Forage } \\
\cline { 2 - 5 } & Sugarcane & Signal grass hay & Corn silage & Elephant grass \\
\hline $\mathrm{B}(\mathrm{g} / 100 \mathrm{~g}$ NDF) & $47.66 \pm 1.19$ & $64.69 \pm 3.05$ & $68.89 \pm 1.40$ & $68.53 \pm 1.83$ \\
$\mathrm{U}(\mathrm{g} / 100 \mathrm{~g}$ NDF) & $52.34 \pm 0.64$ & $35.31 \pm 0.56$ & $31.36 \pm 0.82$ & $31.46 \pm 0.94$ \\
$\mathrm{UB}(\mathrm{U})(\mathrm{g} / 100 \mathrm{~g}$ NDF$)$ & 53.88 & 36.91 & 33.85 & 34.26 \\
$\mathrm{ASD}(\mathrm{g} / 100 \mathrm{~g} \mathrm{NDF})$ & 2.51 & 2.92 & 3.88 & 4.65 \\
$\mathrm{kd}\left(\mathrm{h}^{-1}\right)$ & $0.0207 \pm 0.0035$ & $0.0375 \pm 0.0028$ & $0.0194 \pm 0.0016$ & $0.0216 \pm 0.0025$ \\
$\mathrm{~s}^{2}(\mathrm{u})\left[\left(\mathrm{h}^{-1}\right)^{2}\right]$ & 0.000017 & 0.001000 & $7.38 \times 10^{-6}$ & 0.000032 \\
$\mathrm{P} \mathrm{value}^{2}$ & 0.384 & 0.280 & 0.286 & 0.076 \\
$\mathrm{ct}(\mathrm{h})$ & 165.8 & 98.7 & 171.1 & $--^{3}$ \\
\hline
\end{tabular}

${ }^{1} \mathrm{~B}$, potentially degradable fraction; $\mathrm{U}$, undegradable fraction; $\mathrm{UB}(\mathrm{U})$, upper bound of the asymptotic confidence interval for $\mathrm{U}$ (1 $-\alpha=0.95)$; ASD, asymptotic standard deviation; kd, fractional degradation rate of $B ; s^{2}(u)$, estimate of the variance of the random effect $\mathrm{u}$ associated with $\mathrm{kd}$; ct, critical time to estimate U. ${ }^{2}$ Descriptive level of probability associated with the evaluation of $\mathrm{s}^{2}(\mathrm{u})$ significance. ${ }^{3}$ For details, see Table 4 and Figure 1.

Source: Elaboration of the authors.

Table 3. Characterization of degradation profile of acid detergent fiber of different forages.

\begin{tabular}{lcccc}
\hline \multirow{2}{*}{ Item $^{1}$} & \multicolumn{4}{c}{ Forage } \\
\cline { 2 - 5 } & Sugarcane & Signal grass hay & Corn silage & Elephant grass \\
\hline $\mathrm{B}(\mathrm{g} / 100 \mathrm{~g} \mathrm{NDF})$ & $48.39 \pm 3.73$ & $62.21 \pm 4.43$ & $65.58 \pm 2.17$ & $70.63 \pm 2.33$ \\
$\mathrm{U}(\mathrm{g} / 100 \mathrm{~g}$ NDF $)$ & $51.61 \pm 1.41$ & $37.79 \pm 1.04$ & $34.42 \pm 1.82$ & $29.37 \pm 1.38$ \\
$\mathrm{UB}(\mathrm{U})(\mathrm{g} / 100 \mathrm{~g}$ NDF $)$ & 55.16 & 40.69 & 40.95 & 33.61 \\
$\mathrm{ASD}(\mathrm{g} / 100 \mathrm{~g}$ NDF$)$ & 6.57 & 7.81 & 6.55 & 5.64 \\
$\mathrm{kd}\left(\mathrm{h}^{-1}\right)$ & $0.0128 \pm 0.0033$ & $0.0304 \pm 0.0040$ & $0.0128 \pm 0.0015$ & $0.0185 \pm 0.0019$ \\
$\mathrm{~s}^{2}(\mathrm{u})\left[\left(\mathrm{h}^{-1}\right)^{2}\right]$ & $--{ }^{3}$ & 0.000523 & $3.18 \times 10^{-6}$ & 0.000043 \\
$\mathrm{P} \mathrm{value}$ & $---{ }^{3}$ & 0.400 & 0.362 & 0.016 \\
$\mathrm{ct}(\mathrm{h})$ & 204.1 & 100.8 & 180.2 & $--{ }^{-4}$ \\
\hline
\end{tabular}

${ }^{1} \mathrm{~B}$, potentially degradable fraction; $\mathrm{U}$, undegradable fraction; $\mathrm{UB}(\mathrm{U})$, upper bound of the asymptotic confidence interval for $\mathrm{U}(1$ $-\alpha=0.95)$; ASD, asymptotic standard deviation; $k d$, fractional degradation rate of $\mathrm{B} ; \mathrm{s}^{2}(\mathrm{u})$, estimate of the variance of the random effect $\mathrm{u}$ associated with $\mathrm{kd}$; ct, critical time to estimate $\mathrm{U} .{ }^{2}$ Descriptive level of probability associated with the evaluation of $\mathrm{s}^{2}(\mathrm{u})$ significance. ${ }^{3}$ The $\mathrm{s}^{2}(\mathrm{u})$ tended to zero $\left[\mathrm{s}^{2}(\mathrm{u})<1.0 \times 10^{-8}\right]$. Such pattern generated a calculated t value tending to infinite. Thus, the random effect $u$ was not considered in the adjustment of acid detergent fiber degradation profile in sugarcane. ${ }^{4}$ For details, see Table 4 and Figure 1.

Source: Elaboration of the authors. 
Table 4. Characterization of simulated values of incubation critical time (h) to estimate the undegradable fraction of neutral (NDF) and acid (ADF) detergent fiber in elephant grass sample.

\begin{tabular}{|c|c|c|}
\hline Statistics & NDF & $\mathrm{ADF}$ \\
\hline \multicolumn{3}{|c|}{ Simulated values } \\
\hline Mean & 157.99 & 170.91 \\
\hline Minimum & 68.42 & 49.44 \\
\hline Maximum & 375.64 & 496.91 \\
\hline $\mathrm{s}$ & 41.38 & 60.41 \\
\hline $\mathrm{n}$ & 1000 & 1000 \\
\hline \multicolumn{3}{|c|}{ Distribution adjustment } \\
\hline Distribution type & Inverse Gauss & Lognormal \\
\hline$\mu$ & 157.99 & 170.91 \\
\hline$\sigma$ & 41.31 & 60.47 \\
\hline $\operatorname{ct}(95 \%)^{1}$ & 233.6 & 283.5 \\
\hline$\chi^{2}$ & 0.326 & 0.210 \\
\hline
\end{tabular}

${ }^{1}$ This value corresponds to 95 th percentile for ct distribution.

Source: Elaboration of the authors.

Figure 1. Distribution of probability for critical time (h) required to estimate the undegradable fraction of neutral (a) and acid (b) detergent fiber in elephant grass.
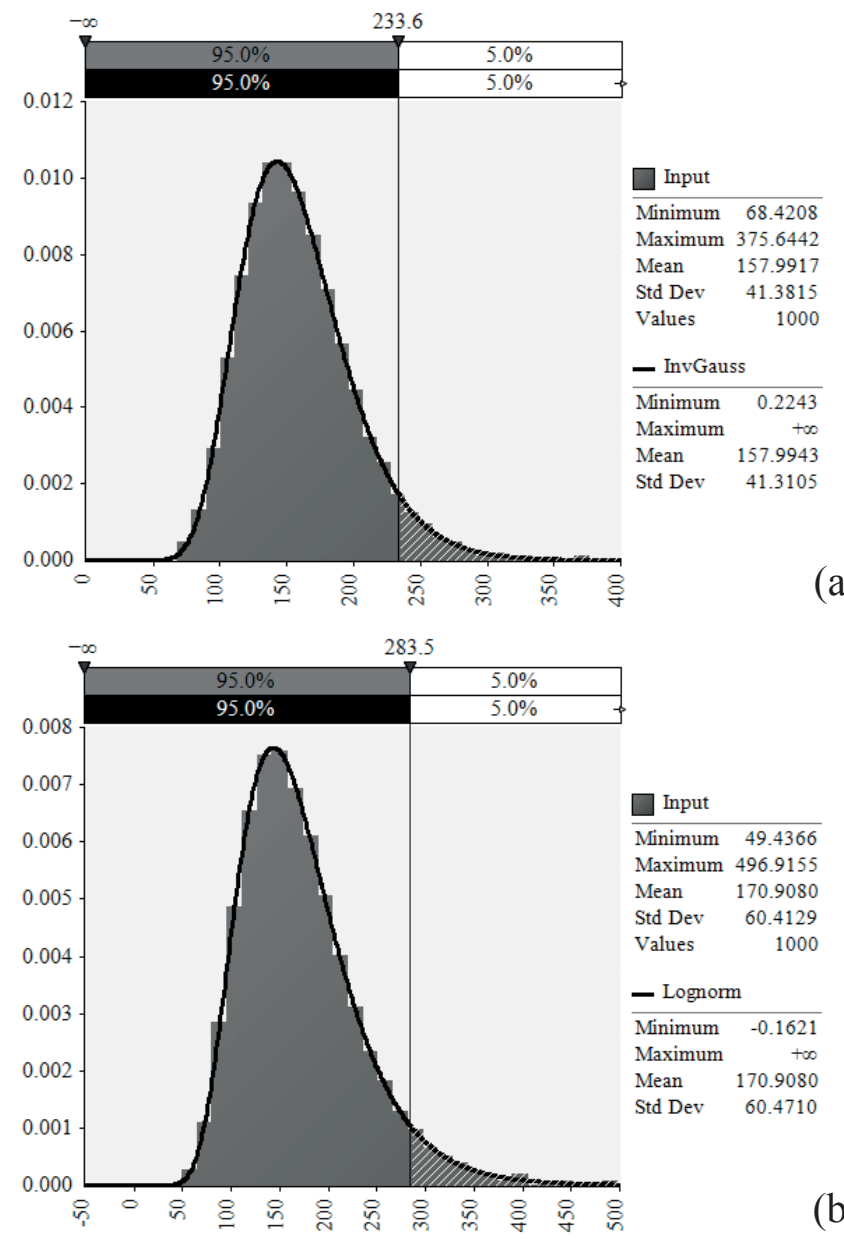

(b)

Source: Elaboration of the authors. 


\section{Discussion}

All obtained estimates for ct in samples of sugarcane, signal grass hay and corn silage (Tables 2 and 3) were compatible with methods suggested for assessing the undegradable fraction in incubation procedures using a single time point, as recommended by Huhtanen, Kaustell and Jaakkola (1994), Casali et al. (2008), Åkerlind et al. (2011) and Valente et al. (2011b). It is worth noting that the divergences between ct values for iNDF and iADF within same feed reflect the difference in the composition of these fibrous residues and were also reported by Casali et al. (2008).

On the other hand, considering the fresh elephant grass sample, we estimated ct values that are equivalent to the 95th percentile of the probability distributions. In other words, this percentile represents the ct value that would result in an accurate estimation of the indigestible fraction for $95 \%$ of the animal population when this experimental procedure is recommended. This result is only possible because the undegradable fraction displays an asymptotic trend (DETMANN; PAULINO; VALADARES FILHO, 2008). Thus, the estimates would not be significantly affected for incubation times greater than the ct values (CASALI et al., 2008). The values obtained for iNDF and iADF were 233.6 and 283.5 hours, respectively (Figure $1)$. The higher value ( 283.5 hours) is compatible with the incubation time suggested by Valente et al. (2011b) and Åkerlind et al (2011) for assessing the iNDF fraction using F57 bags and polyester bags with $10-15 \mu \mathrm{m}$ pores size, respectively (288 hours).

Results obtained with elephant grass showed clear differences among animals regarding fiber degradation rates in the rumen (Tables 2 and 3 ). The diversity of microorganisms able to colonize the ruminal environment remains unclear, with reports identifying more than 2000 species of bacteria (FIRKINS, 2010). Several of these bacterial species use the same substrate as a source of nutrients and may produce dissimilar products (EDWARDS et al.,
2008). Additionally, the composition of the bacterial community is specific for each animal (WEIMER et al., 2010).

Differences among animals with regard the capacity to maintain the physical and chemical characteristics of the rumen have also been reported. The capacity to control the ruminal $\mathrm{pH}$ developed by some animals allows for survival even when receiving diets consisting of $90 \%$ concentrate (RUSSELL; RYCHLIK, 2001). In addition to the diversity of microbial populations in different animals (WEIMER et al., 2010), the recycling of nitrogen, which is partially controlled by symbiotic relationships with microorganisms, also varies (WATERLOW, 2006); therefore, similar animals may differ in terms of their nitrogen retention efficiency in the organism and in the ruminal ecosystem.

The observed variability among animals regarding the elephant grass sample suggests that this variability would also be significant for the other studied feeds. However, the lack of significance could be attributed to the small size of the sample $(\mathrm{n}=5)$. The small number of animals used in this study was due to the difficulty in finding high numbers of fistulated and sufficiently similar animals to allow for an assessment of differences among animals without misinterpretations linked to other factors (e.g., genetics and physiological status).

Assuming that the variability among animals is real, this result readily suggests that the establishment of correct experimental control, according to the basic principles of experimentation, could be needed to obtain unbiased and precise estimates of the concentration of undegradable components. Such experimental control could also help to obtain more precise and accurate adjusted profiles of fiber degradation. Nevertheless, further studies to assess variability among animals are recommended to verify the behavior observed in this study with elephant grass. 


\section{Conclusions}

The results of this study seem to suggest that variation among animals concerning the degradation rate of fiber is significant. However, it is suggested that further evaluations must be done to give a better support for that statement.

\section{Acknowledgements}

To the Conselho Nacional de Pesquisa e Desenvolvimento Científico e Tecnológico (CNPq) and INCT Ciência Animal for financial support. To Fundação de Amparo à Pesquisa de Minas Gerais (FAPEMIG) that provided the post-doctoral scholarship for Cláudia Batista Sampaio.

\section{References}

ÅKERLIND, M.; WEISBJERG, M.; ERIKSSON, T.; TØGERSEN, R.; UDÉN, P.; ÓLAFSSON, B. L.; HARSTAD, O. M.; VOLDEN, H. Feed analyses and digestion methods. In: VOLDEN, H. (Ed.). NorFor - the Nordic feed evaluation system. Wageningen: Academic Publishers, 2011. p. 41-54.

BACH, A.; CALSAMIGLIA, S.; STERN, M. D. Nitrogen metabolism in the rumen. Journal of Dairy Science, Champaign, v. 88, p. E9-E21, 2005. Electronic Supplement.

CASALI, A. O.; DETMANN, E.; VALADARES FILHO, S. C.; PEREIRA, J. C.; HENRIQUES, L. T.; FREITAS, S. G.; PAULINO, M. F. Influence of incubation time and particles size on indigestible compounds contents in cattle feeds and feces obtained by in situ procedures. Revista Brasileira de Zootecnia, Viçosa, MG, v. 37, n. 2, p. 335-342, 2008.

DETMANN, E.; PAULINO, M. F.; MANTOVANI, H. C.; VALADARES, FILHO, S. C.; SAMPAIO, C. B.; SOUZA, M. A.; LAZZARINI, I.; DETMANN, K. S. C. Parameterization of ruminal fibre degradation in lowquality tropical forage using Michaelis-Menten kinetics. Livestock Science, Amsterdam, v. 126, n. 1-3, p. 136-146, 2009.

DETMANN, E.; PAULINO, M. F.; VALADARES FILHO, S. C. Avaliação de alimentos ou de dietas? Uma abordagem conceitual. In: SIMPÓSIO DE PRODUÇÃO DE GADO DE CORTE, 6., 2008, Viçosa. Anais... Viçosa: Departamento de Zootecnia-UFV, 2008. p. 21-52.
DETMANN, E.; SOUZA, M. A.; VALADARES FILHO, S. C.; QUEIROZ, A. C.; BERCHIELLI, T. T.; SALIBA, E. O. S.; CABRAL, L. S.; PINA, D. S.; LADEIRA, M. M.; AZEVEDO, J. A. G. Métodos para análise de alimentos. Instituto Nacional de Ciência e Tecnologia em Ciência Animal. Visconde do Rio Branco: Suprema, 2012. 214 p.

EDWARDS, J. E.; HUWS, S. A.; KIM, E. J.; LEE, M. R. F.; KINGSTON-SMITH, A. H.; SCOLLAN, N. D. Advances in microbial ecosystem concepts and their consequences for ruminant agriculture. Animal, Cambridge, v. 2, n. 5, p. 653-660, 2008.

FIRKINS, J. L. Reconsidering rumen microbial consortia to enhance feed efficiency and reduce environmental impact of ruminant livestock production systems. Revista Brasileira de Zootecnia, Viçosa, MG, v. 39, p. 445-457, 2010. Special Issue.

HUHTANEN, P.; KAUSTELL, K.; JAAKKOLA, S. The use of internal markers to predict total digestibility and duodenal flow of nutrients in cattle given six different diets. Animal Feed Science and Technology, Amsterdam, v. 48, n. 3, p. 211-227, 1994.

LITTELL, R. C.; MILLIKEN, G. A.; STROUP, W. W.; WOLFINGER, R. D.; SCHABENBERGER, O. SAS ${ }^{\circledR}$ for mixed models. 2. ed. Cary: SAS Institute Inc., 2006. 814 p.

RUSSELL, J. B.; RYCHLIK, J. L. Factors that alter rumen microbial ecology. Science, Washington, D.C., v. 292, n. 5519, p.1119-1122, 2001.

TIJMS, H. C. Understanding probability: chance rules in everyday life. Cambridge: Cambridge University Press, 2007. $452 \mathrm{p}$.

TOMICH, T. R.; SAMPAIO, I. B. M. A new strategy for the determination of forage degradability with an in situ technique through the use of one fistulated ruminant. Journal of Agricultural Science, Cambridge, v. 142, n. 5, p. 589-593, 2004.

VALENTE, T. N. P.; DETMANN, E.; QUEIROZ, A. C.; VALADARES FILHO, S. C.; GOMES, D. I.; FIGUEIRAS, J. F. Evaluation of ruminal degradation profiles of forages using bags made from different textiles. Revista Brasileira de Zootecnia, Viçosa, MG, v. 40, n. 11, p. 2565-2573, 2011 b.

VALENTE, T. N. P.; DETMANN, E.; VALADARES FILHO, S. C.; CUNHA, M.; QUEIROZ, A. C.; SAMPAIO, C. B. In situ estimation of indigestible compounds contents in cattle feed and feces using bags made from different textiles. Revista Brasileira de Zootecnia, Viçosa, MG, v. 40, n. 3, p. 666-675, 2011a. 
WATERLOW, J. C. Protein turnover. Cambridge: CAB International, 2006. $301 \mathrm{p}$.
WEIMER, P. J.; STEVENSON, D. M.; MANTOVANI, H. C.; MAN, S. L. C. Host specificity of the ruminal bacterial community in the dairy cow following neartotal exchange of ruminal contents. Journal of Dairy Science, Champaign, v. 93, n. 12, p. 5902-5912, 2010. 